\title{
IS THE PATENT OFFICE A RUBBER STAMP? ${ }^{\dagger}$
}

\author{
Mark A. Lemley* \\ Bhaven Sampat** \\ INTRODUCTION
}

A growing chorus of voices is sounding a common refrain: the U.S. Patent and Trademark Office (PTO) is issuing far too many bad patents. Look almost anywhere and you can find entertaining examples of silly patents that surely should not have issued. ${ }^{1}$ More importantly, critics complain, the PTO is so overworked, and the incentives for examiners to grant patents so great, that the PTO gives patents to the vast majority of applicants. ${ }^{2}$ Compounding the problem, PTO rules permit applicants whose applications are rejected to try an unlimited number of times to get a patent using a "continuation" application. ${ }^{3}$ As a result, some have claimed that the PTO grants patents to as many as $97 \%$ of those who seek them. ${ }^{4}$ On this view, far from serving as an effective

† (C) 2008 Mark A. Lemley \& Bhaven Sampat.

* William H. Neukom Professor, Stanford Law School; of counsel, Keker \& Van Nest LLP.

** Professor, Columbia School of Public Health.

We thank Patrick Crosby at xblabs.com for assistance in obtaining the data used in our analyses and John Allison, Ernie Beffel, Miriam Bitton, Colleen Chien, Chris Cotropia, Lawrence Ebert, Jeanne Fromer, Bill Gallagher, Rose Hagan, Joe Miller, Roberta Morris, David O’Brien, Michael Risch, Kathy Strandburg, two anonymous reviewers, and participants in workshops at Stanford Law School, UMKC Law School, the IP Scholars' Conference, the NYU Conference on Empirical Legal Studies, Microsoft Corporation, and the Advanced Patent Law Institutes in Austin, Texas, and San Jose, California, for comments on an earlier draft.

1 Everyone has their favorite examples. See, e.g., Hyper-Light-Speed Antenna, U.S. Patent No. 6,025,810 (filed Oct. 2, 1997) (method to send a signal faster than the speed of light); Painting Kit and Related Method, U.S. Patent No. 6,213,778 B1 (filed Dec. 14, 1999) (method of painting using a baby's butt). For an entire book devoted to silly patents, see Rick FeInBERG, PECULIAR PATENTS: A COLLECTION OF UnUSUAL AND INTERESTING INVENTIONS FROM THE FILES OF THE U.S. PATENT OFFICE (1994).

2 See Jay P. Kesan \& Andres A. Gallo, Why "Bad” Patents Survive in the Market and How Should We Change?-The Private and Social Costs of Patents, 55 EMORY L.J. 61 (2006); John R. Thomas, Collusion and Collective Action in the Patent System: A Proposal for Patent Bounties, 2001 U. ILL. L. REV. 305, 316-22.

3 See generally Mark A. Lemley \& Kimberly A. Moore, Ending Abuse of Patent Continuations, 84 B.U. L. REV. 63 (2004).

4 See Cecil D. Quillen, Jr. \& Ogden H. Webster, Continuing Patent Applications and Performance of the U.S. Patent and Trademark Office, 11 FED. CIR. B.J. 1, 13 (2001). Quillen and Webster did subsequent work that caused them to revise that number downward, however. See Cecil D. Quillen, Jr., Ogden H. Webster \& Richard Eichmann, Continuing Patent Applications and Performance of the U.S. Patent and Trademark 
gatekeeper, the PTO is effectively rubber-stamping private efforts to seek immunity from competition.

These criticisms are complicated by the rather surprising fact that we do not really know what percentage of patent applications actually issue as patents. Patent applications have historically been kept secret unless and until they issue as patents, meaning that applications that were abandoned or were still pending were never disclosed. The result has been significant controversy over the underlying question of what percentage of applications actually issue as patents.

Recent changes in the law regarding publication and PTO administrative procedure allow us, for the first time, to track what happens to the vast majority of patent applications during prosecution. We now have access to patent applications that are abandoned without a continuation, which allows us to estimate the actual grant rate in the PTO. ${ }^{5}$ It also enables us to learn some significant things about how issued patents differ from rejected patents by examiner, industry area, and prosecution behavior.

We find that the PTO rejects a surprisingly high percentage of patent applications. While approximately $75 \%$ of all applications result in at least one patent, a significant number of applications are rejected and then finally abandoned by the applicant. We also find that the likelihood of obtaining a patent varies significantly by industry in surprising ways. For example, patents are much more likely to be granted in the chemical and pharmaceutical industries than in software and computer fields, despite the fact that most of the complaints about bad patents show up in the information technology (IT) industries.

Part I describes existing uncertainty about various aspects of patent practice and grant rates and explains the data collected. Part II presents our basic findings about grant rates. Part III looks into the significant industry-specific differences in patent numbers, the patent prosecution process, and grant rates. Part IV examines the extent to which continuation applications affect grant rates. Finally, Part V discusses the implications of our findings, both for patent

Office-Extended, 12 FED. CIR. B.J. 35, 38 (2002) (lowering figures by 12\% from earlier calculations) [hereinafter Quillen et al., Extended].

5 See infra notes 32-35 and accompanying text (discussing the Patent Application Information Retrieval database). Because an unknown number of unpublished applications may have been abandoned without ever being published, we can't identify a definitive grant rate for unpublished applications. Oddly, the PTO doesn't give applications entirely sequential numbers, so we can't make inferences from the application numbers. 
policy disputes over the value of the work the PTO does, and for efforts to reform and rationalize patent prosecution.

\section{The SURPRISINGLY DifFicUlt QUESTION OF PATENT GRANT RATES}

\section{A. Controversies over Data}

It seems it should be a simple matter to determine how likely the PTO is to issue a patent: Take the number of patents issued, divide by the number of applications filed, and the result should be the grant rate. There were 164,293 utility patents issued and 356,943 utility patent applications filed in $2004,{ }^{6}$ so the grant rate from this simple calculation is just under $50 \%$. This approach, however, is too simple because patents take time to issue- 2.77 years on average in the late 1990s, ${ }^{7}$ and likely longer today-and the number of applications filed has been increasing dramatically, roughly quadrupling over the past thirty years. ${ }^{8} \quad$ A closer approximation would, accordingly, be the number of patents issued in, say, 2004 divided by the number of applications filed three years earlier. Quillen and Webster used such an approximation in their calculation. ${ }^{9}$ But even this is an approximation, because 2.77 years is just an average. Some patents issue in less than a year, while others spend over a decade in the PTO. ${ }^{10}$

The problem is worse than that, however, for several reasons. First, the term "patent applications" lumps together a number of different documents, only some of which are original applications. Patent applications filed in the PTO may also include continuations, continuations-in-part (CIP), divisionals, and international priority applications. ${ }^{11}$ A significant percentage of these involve applications that have already been presented to the PTO once before,

\footnotetext{
6 PTO, U.S. Patent Statistics Chart, Calendar Years 1963-2007 (June 13, 2008), http://www.uspto.gov/ go/taf/us_stat.htm.

7 John R. Allison \& Mark A. Lemley, Who's Patenting What? An Empirical Exploration of Patent Prosecution, 53 VAND. L. ReV. 2099, 2118 (2000) [hereinafter Allison \& Lemley, Who's Patenting What].

8 See PTO, Number of Utility Patent Applications Filed in the United States, By Country of Origin, Calendar Years 1965 to Present (June 13, 2008), http://www.uspto.gov/go/taf/appl_yr.htm (reporting that the number of applications filed per year increased from 101,014 in 1975 to 390,733 in 2005).

9 Quillen \& Webster, supra note 4, at 9-10.

10 Lemley and Moore document the time spent in the patent office for every patent issued between 1976 and 2000. Lemley \& Moore, supra note 3, at 121-23, app. A. Some spent a striking amount of time in the PTO: one patent spent 68 years in prosecution, another spent 64 years, and 13,282 patents spent more than 10 years in prosecution. Id.

11 Quillen \& Webster, supra note 4, at 4.
} 
so that counting them in the denominator would understate the chance of at least one patent being granted on one original application. ${ }^{12}$ Second, it is possible, and indeed fairly common, that more than one patent will issue based on the same original application because applicants file "families" of continuations and related applications. ${ }^{13}$ Counting these multiple patents in the numerator overstates the grant rate. ${ }^{14}$ Quillen and Webster, in their revised article, sought to correct for these biases, ${ }^{15}$ but others have made the same effort and come out with very different numbers. ${ }^{16}$

Because of these complications, no one can agree on how likely it is that an applicant can get a patent. The PTO reports that the rate historically has been about $66 \%,{ }^{17}$ and that the rate now is only $54 \%,{ }^{18}$ but their estimate doesn't account for continuations. Considering continuations, Quillen and Webster estimated the rate to be as high as $97 \%$ in their original article, ${ }^{19}$ but after revising their calculations, dropped that number to $85 \% .^{20}$ Others, taking account of continuations with different assumptions, find the number to be lower, around $75 \% .^{21}$ The uncertainty and variation in numbers has led others to make wilder claims, such as that the grant rate is less than $50 \%{ }^{22}$

12 See id

13 Quillen et al., Extended, supra note 4, at 37-38.

14 For a nice analysis of the problem, see Bruce A. Kaser, Patent Application Recycling: How Continuations Impact Patent Quality \& What the USPTO Is Doing About It, 88 J. PAT. \& TrademARK OfF. SOC’Y 426 (2006).

15 See Quillen et al., Extended, supra note 4, at 38 (adjusting calculations resulted in a revised estimated grant rate of $85 \%$ ).

16 See Robert A. Clarke, U.S. Continuity Law and Its Impact on the Comparative Patenting Rates of the US, Japan and the European Patent Office, 85 J. PAT. \& TRADEMARK OFF. SOC’Y 335, 335 (2003) (finding a grant rate of 75\%); see also Lawrence B. Ebert, How High Are the Grant Rates at the USPTO?, 86 J. PAT. \& TRADEMARK OFF. SOC'Y 568, 568-69 (2004) (arguing that Clarke's result of a 75\% grant rate is more reasonable than Quillen and Webster's revised numbers).

17 See E-mail to Cecil D. Quillen, Jr., Senior Advisor, Cornerstone Research, from Robert W. Bahr, Senior Patent Attorney, Office of the Deputy Comm'r for Patent Examination Policy (Apr. 22, 2006, 3:31 PM), available at http://www.uspto.gov/web/offices/pac/dapp/opla/comments/fpp_continuation/quillen.pdf (stating that the uncorrected grant rate for the PTO for its fiscal years 1993-1998 is 66\%).

18 See Harold Wegner, The USPTO's 54\% Allowance Rate, IPFRONTLINE, Dec. 30, 2006, http://www. ipfrontline.com/depts/article.asp?id=13796\&deptid=5 (stating that the PTO announced a $54 \%$ allowance rate).

19 See Quillen \& Webster, supra note 4, at 3.

20 See Quillen et al., Extended, supra note 4, at 38.

21 See Clarke, supra note 16, at 335; Ebert, supra note 16, at 569; Ron D. Katznelson, Bad Science in Search of "Bad” Patents, 17 FED. CIR. B.J. 1, 23 fig.2 (2007) (offering a running estimated grant rate of $59 \%-71 \%$ from 2000 through 2005).

22 See, e.g., Craig Allen Nard, The Law of Patents 34 (2008) (asserting PTO grants patents on 39\% of applications); Brief of the Boston Patent Law Ass'n as Amicus Curiae in Support of Genentech, Inc., on the Merits at 5, Medimmune, Inc. v. Genentech, Inc., 549 U.S. 118 (2007) (No. 05-608) (stating that only about $50 \%$ of applications become patents); Erik Belt, Medimmune Licensing Wars, DisPATCH (Bromberg \& 


\section{B. Why It Matters}

Both the PTO grant rate and the use of continuation applications are at the heart of raging controversies over patent reform. The unprecedented modern Supreme Court interest in patent cases ${ }^{23}$ and congressional interest in patent reform ${ }^{24}$ are both driven in part by the widespread perception that the PTO is acting as a rubber stamp, regularly issuing bad patents that wind up imposing costs on others. That has, in turn, produced proposals to spend more time and money in the PTO weeding out bad patents, ${ }^{25}$ to establish post-grant opposition systems allowing administrative challenges to bad patents, ${ }^{26}$ to create a twotiered patent system in which patentees can opt into a more rigorous examination for important applications, ${ }^{27}$ and to eliminate the clear and

Sunstein LLP, Boston, Mass.), Winter 2007, at 1, available at http://www.bromsun.com/media/Medimmune EB.pdf (same).

23 The Supreme Court heard, decided, or granted certiorari in six patent cases in 2006, more than in any year since 1965. On the Court's relative inactivity until recently, see, for example, John F. Duffy, The Festo Decision and the Return of the Supreme Court to the Bar of Patents, 2002 SuP. CT. REV. 273.

24 See, e.g., Patent Reform Act of 2007, H.R. 1908, 110th Cong. (as passed by H. Comm. on the Judiciary, Sept. 7, 2007) (proposing significant changes in U.S. patent laws).

25 Complaints about patent quality are legion. See, e.g., Julie E. Cohen, Reverse Engineering and the Rise of Electronic Vigilantism: Intellectual Property Implications of "Lock-Out” Programs, 68 S. CAL. L. REV. 1091, 1177-80 (1995) (pointing out shortfalls in the PTO patent process in the area of computers and computer programs); Shubha Ghosh \& Jay Kesan, What Do Patents Purchase? In Search of Optimal Ignorance in the Patent Office, 40 Hous. L. REV. 1219, 1227-35 (2004) (exploring the social and private costs and persistence of bad patents); Robert P. Merges, As Many as Six Impossible Patents Before Breakfast: Property Rights for Business Concepts and Patent System Reform, 14 BERKELEY TeCH. L.J. 577, 589-91 (1999) (arguing that the patent system is in crisis due to the poor quality of patents); John R. Thomas, Collusion and Collective Action in the Patent System: A Proposal for Patent Bounties, 2001 U. ILL. L. REV. 305, 316-22 (arguing that the PTO is a porous agency); Simson L. Garfinkel, Patently Absurd, WIRED, July 1994, at 104, available at http://www.wired.com/wired/archive/2.07/patents.html (criticizing PTO for issuing a steady stream of overly broad patents); James Gleick, Patently Absurd, N.Y. TIMES, Mar. 12, 2000 (Magazine), at 44 (calling Internet patents a "ridiculous phenomenon”); Lawrence Lessig, The Problem with Patents, IndUSTRY STANDARD, Apr. 23, 1999, http://www.lessig.org/content/standard/0,1902,4296,00.html (stating that bad patents have become common on the Internet); Bezos and O’Reilly Spearhead Call for Patent Reform, An Open Letter from Jeff Bezos on the Subject of Patent Reform (Mar. 9, 2000), http://www.oreilly.com/news/amazon_patents.html (alleging that current patent rules are harmful to businesses and shareholders).

26 See H.R. $1908 \S \S 321-335$. For a discussion of post-grant review proposals, see Mark D. Janis, Rethinking Reexamination: Toward a Viable Administrative Revocation System for U.S. Patent Law, 11 HARV. J.L. \& TeCH. 1, 117-22 (1997); Merges, supra note 25, at 610-15; Craig Allen Nard, Certainty, Fence Building, and the Useful Arts, 74 IND. L.J. 759 (1999); Thomas, supra note 25, at 333-40. See generally J.H. Reichman, From Free Riders to Fair Followers: Global Competition Under the TRIPS Agreement, 29 N.Y.U. J. INT'L L. \& POL. 11 (1996-1997).

27 See Doug Lichtman \& Mark A. Lemley, Rethinking Patent Law's Presumption of Validity, 60 STAN. L. REV. 45 (2007) (arguing for the creation of two-tiered system of patent validity); Mark A. Lemley, Doug Lichtman \& Bhaven Sampat, What to Do About Bad Patents, REgUlation, Winter 2005-2006, at 10, 12-13 (same). 
convincing evidence presumption as unwarranted. ${ }^{28}$ All these proposals are based on the assumption that the PTO is not doing a good job of weeding out bad patent applications.

Continuation applications are also the subject of continued policy controversy. Congress passed a number of changes in 1994, and more in 1999, to deal with the abuse of continuation practice by "submarine patentees." 29 The PTO recently proposed significant restrictions on continuation practice to deal with remaining abuses. ${ }^{30}$ In response, patent applicants and lawyers have claimed that problems with continuations were solved in the 1990s and that further reform is unnecessary, and have challenged the PTO regulations in court. $^{31}$

Understanding how many applications the PTO rejects, or how many times applicants come back for "do overs" using the continuation process, won't tell us the right level of PTO scrutiny of patent applications. We do not, and cannot, know the "right" grant rate, or how many continuations are being used for abusive as opposed to legitimate purposes. If the grant rate were $97 \%$, that could still be "too low" if it turned out that every application filed was meritorious. Similarly, a grant rate of $5 \%$ could be too high if none were meritorious. There is no way to know the answer to that question for certain. But knowing what the PTO and applicants are actually doing is a prerequisite to informed policy debate on these issues.

\section{Our Data}

We take a novel approach to collecting data on these issues. Rather than looking at overall filings and issued patents in the aggregate to try to measure ratios, we identify a group of patent applications, which we then follow through the process. Specifically, we collected every original utility patent application filed in the month of January 2001 that was published by April

\footnotetext{
28 See, e.g., Mark A. Lemley, Rational Ignorance at the Patent Office, 95 Nw. U. L. REV. 1495, 1528-29 (2001) (proposing that the presumption of validity be rebuttable by a preponderance of the evidence); Lichtman \& Lemley, supra note 27 (arguing that a strong presumption of validity is unjustified today).

2935 U.S.C. $\S \S 122(\mathrm{~b})(1)(\mathrm{A}), 154(\mathrm{a})(2)$ (2000); see Lemley \& Moore, supra note 3, at 80 (discussing these legislative changes).

30 See Changes to Practice for Continuing Applications, Requests for Continued Examination Practice, and Applications Containing Patentably Indistinct Claims, 71 Fed. Reg. 48 (proposed Jan. 3, 2006) (to be codified at 37 C.F.R. pt. 1).

31 See, e.g., Tafas v. Dudas, 541 F. Supp. 2d 805 (E.D. Va. 2008) (a successful challenge to PTO rules by pharmaceutical company and inventor).
} 
2006. ${ }^{32}$ After eliminating plant, design, and reissue patents, Patent Cooperation Treaty applications directed at foreign filing, continuations, divisionals, and CIPs based on earlier applications, we were left with 9,960 applications. We then collected every "transaction" for each of these patent applications - every filing or act by the patentee and every action by the PTO—from the PTO's Patent Application Information Retrieval (PAIR) database as of April 2006. For those applications still pending at that date, we revisited PAIR in April 2008 and updated their status.

The advantage of this approach is that, for those applications, we can get accurate, verifiable data on the questions that have vexed patent lawyers and policy makers. Until 1999, such an approach was impossible because patent applications were not published unless and until they issued as patents. Beginning with applications filed this millennium, the vast majority of patent applications are published eighteen months after filing, and most of the rest are published sixty months after filing. ${ }^{33}$ For each of these applications, we determine whether a continuation of any type was filed. We then ask whether the patent application or any of its continuation "children" were ultimately patented, were abandoned without any continuation being filed, ${ }^{34}$ or were still pending more than seven years after the original application was filed.

PAIR data has other significant advantages. Because we collect all the transaction data, we can report a wealth of data about the way the PTO treats applications-how many receive first-action allowances, allow patents after rejection, require appeals, and so forth. ${ }^{35}$ We can also track the pertinent differences in the treatment of applications by area of technology.

While our approach has a number of advantages, one significant disadvantage is that we sample only published applications. Applications

\footnotetext{
32 We chose January 2001 because it was the first month in which applications would reliably be published eighteen months after filing in most cases. It is possible that there is something atypical about this month, but we are unaware of any systematic bias. We address one issue - the changing economy in the early part of this decade, especially for Internet patents-infra note 60 and accompanying text.

3335 U.S.C. § 122(b) (setting out the rule and describing the exceptions, chiefly for applicants who agree not to file counterpart applications abroad).

34 Oddly, there is no actual way for the PTO to finally reject a patent. Lemley \& Moore, supra note 3, at 64. We consider a patent application to have been finally abandoned if the applicant has filed a notice of abandonment or has not responded to a PTO rejection for over six months and has not filed an appeal or any form of continuation. Even then, it is conceivable that an applicant can revive an abandoned application if she can prove that the delay was "unavoidable.” 35 U.S.C. $§ 133$.

35 We discuss those findings in detail in a companion paper. See Mark A. Lemley \& Bhaven Sampat, Patent Prosecution by the Numbers (2008) (unpublished manuscript, on file with authors).
} 
granted or abandoned before eighteen months do not appear in our analyses unless the applicant affirmatively chooses to ask for early publication. Data from granted patents suggests that about $17 \%$ of patents are granted before eighteen months; of these, about half (46\%) are published pre-grant. It is likely that some applications are finally abandoned before eighteen months have passed and never show up either in the dataset or as issued patents. If the characteristics of published applications are systematically different than those of unpublished applications, this would limit our ability to draw inferences applicable to the broader population.

A more serious issue is that even applications pending more than eighteen months can "opt-out" of publication if they don't have corresponding foreign applications, or if they have corresponding foreign applications but also have priority dates pre-dating the effective date of the law requiring publication. ${ }^{36}$ To the extent such opt-out is systematically related to characteristics of interest, our conclusions about the grant rate, would be biased. Accordingly, in a separate analysis we examined opt-out patterns in detail. While opt-out of publication is nonrandomly distributed across applications, we show that our main conclusions do not change if we limit our analysis to the subsample of applications for which opt-out was not possible. This gives us some confidence that the missing data does not skew our results in a systematic way. ${ }^{37}$

\section{GRANT RATES}

As we noted above, calculating grant rates is not a simple matter of measuring grant versus rejection. The PTO has no power to finally reject a patent; the applicant can always come back and argue that the examiner should change her mind. Further, even seven and a half years after the applications in our cohort were filed, a number of those applications are still pending. We therefore can establish not a grant rate but a grant range, bounded on the lower end by the percentage of original applications that have already received a patent, and on the upper end by the percentage of applications that have been

36 See 35 U.S.C. § 122(b)(2)(B) (2000) (opt-out for U.S.-only applications); American Inventors Protection Act of 1999, Pub. L. No. 106-113, 113 Stat. 1501 (codified at scattered sections of 35 U.S.C.) (transition period implementing publication for applications with priority dates after November 2000).

37 In the interests of space, we have not published that analysis here, but it is available upon request from the authors. 
abandoned. Table 1 presents first-order results updated to April 2008, not including the effect of continuations.

\section{Table 1: Status of Applications in Sample}

\begin{tabular}{|l|l|l|}
\hline \multicolumn{1}{|c|}{ Status } & \multicolumn{1}{c|}{ N } & \multicolumn{1}{c|}{ Share of Total } \\
\hline Abandoned & 2,724 & $27.3 \%$ \\
\hline Patented & 7,020 & $70.5 \%$ \\
\hline Pending & 216 & $2.2 \%$ \\
\hline Total & $\mathbf{9 , 9 6 0}$ & $\mathbf{1 0 0} \%$ \\
\hline
\end{tabular}

These results generally track the PTO's estimate of about a two-thirds grant rate, but several issues complicate making an inference about the overall grant rate from these figures. First, it is important to emphasize that a $27.3 \%$ abandonment rate is not necessarily evidence that the PTO rejects $27.3 \%$ of all patent applications. Some of these abandonments presumably reflect business decisions by the applicant not to pursue the application, either because the company as a whole went out of business or because the company's plans or interests changed. We explore some data that might suggest what caused abandonment in the next Part. Second, the data in Table 1 don't take into account the possibility of applicants filing continuations and obtaining patents on those continuations even if they have abandoned the original application. We also examine this in the following Part.

\section{CORRECTIONS TO THE BASE GRANT RATE}

\section{A. The Impact of Continuations on the Grant Rate}

The grant ranges we reported in Part II do not take into account the possibility of applicants filing continuations and obtaining patents on those continuations. This could cause the lower bound of the grant range to increase because some applications that were either abandoned or pending might have continuations that have themselves resulted in a patent. Five and a half years after the roughly 10,000 applications in our study were filed, those applicants 
had filed 2,016 distinct "children"-ordinary continuations, CIPs, or divisionals based ultimately on those original applications. ${ }^{38}$ Table 2 shows that roughly one-third of those children are "ordinary" continuations, and slightly less than $40 \%$ are divisionals, with the remainder being CIPs or applications for which we could not determine continuation type from the PAIR data.

\section{Table 2: Distribution of Continuation Types}

\begin{tabular}{|l|l|l|}
\hline \multicolumn{1}{|c|}{ Continuation Type } & \multicolumn{1}{c|}{$\mathrm{N}$} & \multicolumn{1}{c|}{ Share of Total } \\
\hline Continuation & 608 & $30.16 \%$ \\
\hline Continuation-in-Part & 422 & $20.94 \%$ \\
\hline Divisional & 770 & $38.19 \%$ \\
\hline Unknown or Not Determinable & 216 & $10.71 \%$ \\
\hline Total & $\mathbf{2 , 0 1 6}$ & $\mathbf{1 0 0 . 0 0 \%}$ \\
\hline
\end{tabular}

Table 3 shows that nearly half these children have themselves already issued as patents, though not surprisingly, given their later filing date, a large percentage of these continuation applications are still pending.

\section{Table 3: Status of Child Applications}

\begin{tabular}{|l|l|l|l|l|}
\hline \multicolumn{1}{|c|}{ Continuation Type } & $\mathrm{N}$ & $\begin{array}{c}\text { Share } \\
\text { Abandoned }\end{array}$ & $\begin{array}{c}\text { Share } \\
\text { Patented }\end{array}$ & $\begin{array}{c}\text { Share } \\
\text { Pending }\end{array}$ \\
\hline Continuation & 608 & $11.5 \%$ & $43.9 \%$ & $44.6 \%$ \\
\hline Continuation-in-Part & 422 & $18.5 \%$ & $55.2 \%$ & $26.3 \%$ \\
\hline Divisional & 770 & $10.8 \%$ & $57.0 \%$ & $32.2 \%$ \\
\hline
\end{tabular}

38 Because of changes in the way the PTO allows access to data, we were unable to update this data to April 2008. As a result, the continuation data in this section are current only through April 2006. 
How do continuations affect the overall grant rate numbers cited in Table 1? In part, this depends on the status of the original applications on which they were based. Table 4 shows the share of applications with a continuation (of any of the types above) by application status as of April 2006.

Table 4: Share of Parent Applications with Continuations, by Status of Parent

\begin{tabular}{|l|l|}
\hline Status of Parent Application & Share with Any Continuation \\
\hline Abandoned & $13 \%$ \\
\hline Patented & $16 \%$ \\
\hline Pending & $7 \%$ \\
\hline All Parent Applications & $\mathbf{1 4 \%}$ \\
\hline
\end{tabular}

About $7 \%$ of pending applications had continuations; to the extent that these continuation applications were patented, this would raise the lower bound of the grant rate. Further, 13\% of the abandoned applications have continuation applications. Patenting these continuations would raise the upper bound of the grant range because some patents classified as finally abandoned (i.e., rejected) in fact ultimately result in a patent. Table 5 shows the share of applications with at least one child pending by status of the original application, again as of April 2006. ${ }^{39}$

39 These numbers differ from the numbers in Table 4 because Table 4 measures the number of continuations filed, while Table 5 measures only those continuations that are still pending. As Table 3 makes clear, many of the continuation applications have already been dealt with by the PTO. 
Table 5: Parent Applications with and Without Children Pending, by Status of Parent

\begin{tabular}{|c|c|c|c|}
\hline & $\begin{array}{c}\text { No Children } \\
\text { Pending } \\
\text { N } \\
\text { Row\% } \\
\text { Column\% }\end{array}$ & $\begin{array}{c}\text { Children } \\
\text { Pending } \\
\text { N } \\
\text { Row\% } \\
\text { Column\% }\end{array}$ & $\begin{array}{c}\text { Total } \\
\mathrm{N} \\
\text { Row\% } \\
\text { Column\% }\end{array}$ \\
\hline Abandoned & $\begin{array}{l}2,328 \\
95.18 \% \\
24.93 \% \\
\end{array}$ & $\begin{array}{l}118 \\
4.82 \% \\
18.97 \% \\
\end{array}$ & $\begin{array}{l}2,446 \\
100.0 \% \\
24.56 \% \\
\end{array}$ \\
\hline Patented & $\begin{array}{l}6,207 \\
93.11 \% \\
66.47 \% \\
\end{array}$ & $\begin{array}{l}459 \\
6.89 \% \\
73.79 \% \\
\end{array}$ & $\begin{array}{l}6,666 \\
100.0 \% \\
66.93 \% \\
\end{array}$ \\
\hline Pending & $\begin{array}{l}803 \\
94.69 \% \\
8.60 \% \\
\end{array}$ & $\begin{array}{l}45 \\
5.31 \% \\
7.23 \% \\
\end{array}$ & $\begin{array}{l}848 \\
100.0 \% \\
8.51 \% \\
\end{array}$ \\
\hline Total & $\begin{array}{l}9,338 \\
93.76 \% \\
100.0 \% \\
\end{array}$ & $\begin{array}{l}622 \\
6.24 \% \\
100.0 \% \\
\end{array}$ & $\begin{array}{l}9,960 \\
100.0 \% \\
100.0 \% \\
\end{array}$ \\
\hline
\end{tabular}

If we treat abandoned applications with pending continuations as "pending," the percentage of applications pending as of April 2006 increases from 8.5\% to $9.7 \%$. Similarly, we can examine the share of continuations that are patented by the status of the original application. 
Table 6: Parent Applications with and Without Children Patented, by Status of Parent

\begin{tabular}{|c|c|c|c|}
\hline & $\begin{array}{c}\text { No Children } \\
\text { Patented } \\
\text { N } \\
\text { Row\% } \\
\text { Column\% }\end{array}$ & $\begin{array}{c}\text { Children } \\
\text { Patented } \\
\text { N } \\
\text { Row\% } \\
\text { Column\% }\end{array}$ & $\begin{array}{c}\text { Total } \\
\mathrm{N} \\
\text { Row\% } \\
\text { Column\% }\end{array}$ \\
\hline Abandoned & $\begin{array}{l}2,313 \\
94.56 \% \\
25.16 \%\end{array}$ & $\begin{array}{l}133 \\
5.44 \% \\
17.34 \%\end{array}$ & $\begin{array}{l}2,446 \\
100.0 \% \\
24.56 \%\end{array}$ \\
\hline Patented & $\begin{array}{l}6,047 \\
90.71 \% \\
65.78 \%\end{array}$ & $\begin{array}{l}619 \\
9.29 \% \\
80.70 \%\end{array}$ & $\begin{array}{l}6,666 \\
100.0 \% \\
66.93 \%\end{array}$ \\
\hline Pending & $\begin{array}{l}833 \\
98.23 \% \\
9.06 \%\end{array}$ & $\begin{array}{l}15 \\
1.77 \% \\
1.96 \%\end{array}$ & $\begin{array}{l}848 \\
100.0 \% \\
8.51 \%\end{array}$ \\
\hline Total & $\begin{array}{l}9,193 \\
92.30 \% \\
100.0 \%\end{array}$ & $\begin{array}{l}767 \\
7.70 \% \\
100.0 \%\end{array}$ & $\begin{array}{l}9,960 \\
100.0 \% \\
100.0 \%\end{array}$ \\
\hline
\end{tabular}


About 5\% of abandoned applications, and 2\% of pending applications, have children that are patented, compared to $9 \%$ of patented applications. The bulk of applications with at least one child patented, over $80 \%$, were themselves patented. As a result, continuations have a more modest effect on the grant rate than their overall numbers might suggest. Once we take continuations into account, the share of the January 2001 original applications that resulted in patents or that had children resulting in patents as of April 2006, is 68.4\%, and the percentage of applications or continuations pending increases to $9.7 \%$. Accordingly, the grant range as of that date runs from a lower bound of $68.4 \%$ to an upper bound of $78.1 \%$.

Updating the data to April 2008 allows us to narrow that grant range significantly, because many of the applications pending in 2006 have been either finally abandoned or have resulted in a patent. Of the 848 applications that were pending in 2006, 354 have since issued as patents, and another 278 have since been finally abandoned. This means that the grant range as of April 2008 runs from a lower bound of $71.8 \%$ to an upper bound of $75.9 \%$. This is higher than the PTO's estimate, but significantly lower than the QuillenWebster estimates and the fears of many advocates of patent reform. While the overall grant numbers are higher than the grant rates from foreign patent offices, ${ }^{40}$ they are not radically different. ${ }^{41}$ Even after accounting for continuations, the odds of an applicant getting a patent are pretty good, but it is an exaggeration to say that the PTO is a rubber stamp.

\section{B. Does Abandonment Imply Rejection?}

The relatively high rate of abandonment does not necessarily mean that the PTO is rejecting all those applications, however. Some of the abandonments occur for business reasons, rather than because the PTO refused to issue the patent. To estimate the magnitude of this effect, we identified the last transaction before abandonment for all applications abandoned and not re-filed. There were 2,444 applications that were finally abandoned as of April 2006, and 2,127 of those had no continuations filed. For each of those 2,127, we classified the last transaction record in PAIR other than an express

40 See Quillen et al., Extended, supra note 4, at 47-48 \& fig.9 (concluding that the European Patent Office and the Japanese Patent Office had grant rates $25 \%-30 \%$ less than the PTO).

41 But cf. Paul H. Jensen et al., Disharmony in International Patent Office Decisions, 15 FED. CIR. B.J. 679, 681 (2006) (finding that many applications granted in the PTO had counterpart applications rejected in the European and Japanese Patent Offices). 
abandonment. $^{42}$ Of those 2,127, 1,470 (69.1\%) were abandoned after a substantive office action, an appeal, or a petition decision. Presumably, many (though probably not all) of these abandonments reflect a decision by the applicant to give up because the PTO would not grant a patent. By contrast, the remaining $30.9 \%$ of abandonments came after nonsubstantive office communications, or even after notices of allowance, suggesting that these abandonments were probably entered for business reasons rather than because of a substantive decision by the PTO. ${ }^{43}$ As a result, while fewer applications make it through the PTO than some critics fear, the share of applications actually rejected on the merits by the PTO-what one might call its examination rigor-is rather lower than the grant range suggests. Applications abandoned without continuations represent $24.1 \%$ of all applications filed. But since at most only $69.1 \%$ of those represent abandonment due to a substantive rejection, the PTO has so far actually managed to reject on the merits only $16.7 \%$ of the applications before it. Another $2.2 \%$ of applications are pending, so the substantive rejection rate will doubtless rise somewhat, but will never be as high as $20 \%{ }^{44}$

\section{INDUSTRY-SPECIFIC DIFFERENCES}

There is a growing body of economic evidence suggesting that different industries experience the patent system in very different ways. ${ }^{45}$ A great deal of work has focused on the seemingly polar opposition between the biopharmaceutical industries, where patents are extremely important and generally considered a positive force, and the IT industries, where patents are often viewed as interfering with, rather than promoting, innovation. Our data

\footnotetext{
42 We did not update this data to April 2008 because changes in the PAIR database made it impossible to automate collection of the information.

43 It is possible that some of these applications were abandoned for substantive reasons other than PTO rejections, such as the discovery of new prior art or a foreign patent office's rejection. But even if that is true, substantive PTO action did not cause the abandonment in those cases.

44 Because of changes in the PAIR system, we obtained the last transaction only for the April 2006 abandonments, not for the additional 278 abandonments between April 2006 and April 2008. We have extrapolated those figures using the same $69.1 \%$ ratio. If it differed, the numbers in text could change somewhat, but not by very much.

45 See, e.g., Dan L. Burk \& Mark A. Lemley, The Patent Crisis, and How Courts Can Solve It (forthcoming 2009); John R. Allison \& Mark A. Lemley, The Growing Complexity of the United States Patent System, 82 B.U. L. REV. 77, 91-94 (2002) [hereinafter Allison \& Lemley, Growing Complexity] (documenting the different experiences that different industries had in patent prosecution); Dan L. Burk \& Mark A. Lemley, Policy Levers in Patent Law, 89 VA. L. REV. 1575, 1589-95 (2003) (describing the "industry-specific nature of the patent system”).
} 
provides strong support for the proposition that there are significant industryspecific differences in patent prosecution, though the ways in which they differ will surprise many.

\section{A. Patent Applications by Industry}

We begin with use of the patent system by different industries more generally. Table 7 reports on the number of applications in our study by art unit. Art units are coarse and imperfect measures of technology class or industry, but they give a general sense of technological differences. ${ }^{46}$

Table 7: Distribution of January 2001 Applications by PTO Art Unit

\begin{tabular}{|l|l|l|}
\hline \multicolumn{1}{|c|}{ Art Unit } & \multicolumn{1}{|c|}{$\mathrm{N}$} & \multicolumn{1}{c|}{$\begin{array}{c}\text { Share of } \\
\text { Applications }\end{array}$} \\
\hline $\begin{array}{l}\text { 1600 Biotechnology and Organic Chemistry } \\
\text { (Art Units 1600-61) }\end{array}$ & 425 & $4.3 \%$ \\
\hline $\begin{array}{l}\text { 1700 Chemical and Materials Engineering } \\
\text { (Art Units 1700-75) }\end{array}$ & 1,407 & $14.1 \%$ \\
\hline $\begin{array}{l}\text { 2100 Computer Architecture, Software, \& } \\
\text { Information Security } \\
\text { (Art Units 2100-95) }\end{array}$ & 1,074 & $10.8 \%$ \\
\hline $\begin{array}{l}\text { 2600 Communications } \\
\text { (Art Units 2600-97) }\end{array}$ & 1,541 & $15.5 \%$ \\
\hline $\begin{array}{l}\text { 2800 Semiconductors, Electrical and Optical } \\
\text { Systems and Components } \\
\text { (Art Units 2800-91) }\end{array}$ & 2,508 & $25.2 \%$ \\
\hline $\begin{array}{l}\text { 3600 Transportation, Construction, } \\
\text { Electronic Commerce, Agriculture, National } \\
\text { Security, and License and Review } \\
\text { (Art Units 3610-83) }\end{array}$ & 1,553 & $15.6 \%$ \\
\hline $\begin{array}{l}\text { 3700 Mechanical Engineering, } \\
\text { Manufacturing, and Products } \\
\text { (Art Units 3700-67) }\end{array}$ & 1,452 & $14.6 \%$ \\
\hline
\end{tabular}

46 On the many problems with PTO classification systems, see Allison \& Lemley, Who's Patenting What, supra note 7, at 2114. 
What is interesting about this data is the predominance of what are broadly defined as the IT industries-computer hardware, software, communications, semiconductors, and electronics. Together, these applications account for more than $50 \%$ of all published patent applications, a number far in excess of their proportion of issued patents in the 1970 s or even in the $1990 \mathrm{~s}^{47}$ Appendix A breaks the industry character down further, identifying the fifty largest patent classes in our study. ${ }^{48}$ Those data may tell us more about the breadth of individual PTO classes than the popularity of technologies, but it is notable that the single largest class was Class 705, covering business methods and financial services patents. ${ }^{49}$

\section{B. Grant Rates by Industry}

The industry-specific differences in grant rates are dramatic. Table 8 reports the status of applications by art unit as of April 2008, not adjusted for continuation applications.

47 Allison and Lemley found that 24.2\% of patents issued between 1996 and 1998 were computer-related inventions (including both hardware and software), $7.7 \%$ were electronics, and another $9.3 \%$ were semiconductor inventions. Even if we include the $4.1 \%$ that were communications-related, not all of which involved IT, that totals only $45.3 \%$. Further, in the 1970 s the numbers were much smaller- $7.4 \%$ computer related, $2.3 \%$ semiconductors, $18.3 \%$ in electronics, and 3.3\% communications, for a total of $31.3 \%$. Allison \& Lemley, Growing Complexity, supra note 45, at 93 tbl.1. Allison and Lemley's numbers are not strictly comparable to ours because they involve issued patents rather than applications, but they are broadly indicative of a difference between the past and today.

48 Classes, too, are notoriously imprecise measures of technology area. See Allison \& Lemley, Who's Patenting What, supra note 7, at 2114.

49 See John R. Allison \& Starling D. Hunter, On the Feasibility of Improving Patent Quality One Technology at a Time: The Case of Business Methods, 21 BERKELEY TECH. L.J. 729, $764-68$ (2006) (documenting how Class 705 understates the number of business method patents because applicants characterize their inventions in ways that avoid the second level of scrutiny applied to this class); $c f$. John R. Allison \& Emerson H. Tiller, The Business Method Patent Myth, 18 BeRKELEY TECH. L.J. 987, 1082-83 (2003) (finding that business method patents are not measurably worse than other patents). 
Table 8: Status of January 2001 Applications by PTO Art Unit

\begin{tabular}{|l|l|l|l|}
\hline \multicolumn{1}{|c|}{ Art Unit } & \multicolumn{1}{|c|}{$\begin{array}{c}\text { Share } \\
\text { Abandoned }\end{array}$} & $\begin{array}{c}\text { Share } \\
\text { Patented }\end{array}$ & $\begin{array}{c}\text { Share } \\
\text { Pending }\end{array}$ \\
\hline $\begin{array}{l}\text { 1600 Biotechnology and Organic } \\
\text { Chemistry } \\
\text { (Art Units 1600-61) }\end{array}$ & $34.6 \%$ & $61.6 \%$ & $3.8 \%$ \\
\hline $\begin{array}{l}\text { 1700 Chemical and Materials } \\
\text { Engineering } \\
\text { (Art Units 1700-75) }\end{array}$ & & & \\
\hline $\begin{array}{l}\text { 2100 Computer Architecture, } \\
\text { Software \& Information Security } \\
\text { (Art Units 2100-95) }\end{array}$ & $36.3 \%$ & $74.2 \%$ & $0.4 \%$ \\
\hline $\begin{array}{l}\text { 2600 Communications } \\
\text { (Art Units 2600-97) }\end{array}$ & $27.7 \%$ & $57.5 \%$ & $6.1 \%$ \\
\hline $\begin{array}{l}\text { 2800 Semiconductors, Electrical } \\
\text { and Optical Systems and } \\
\text { Components } \\
\text { (Art Units 2800-91) }\end{array}$ & & $68.4 \%$ & $3.9 \%$ \\
\hline $\begin{array}{l}\text { 3600 Transportation, } \\
\text { Construction, Electronic } \\
\text { Commerce, Agriculture, } \\
\text { National Security, and License } \\
\text { and Review } \\
\text { (Art Units 3610-83) }\end{array}$ & $17.1 \%$ & $82.6 \%$ & $0.2 \%$ \\
\hline $\begin{array}{l}\text { 3700 Mechanical Engineering, } \\
\text { Manufacturing, and Products } \\
\text { (Art Units 3700-67) }\end{array}$ & & $59.6 \%$ & $3.4 \%$ \\
\hline
\end{tabular}

The chance of getting a patent differs significantly by industry. Patented applications - the lower end of the grant range-vary from a low of $57.5 \%$ in computer hardware and software to a high of $82.6 \%$ in semiconductors and electronics. Some of this variation is a function of differences in pending applications and, therefore, presumably of industry-specific differences in the speed with which the PTO processes applications. Indeed, a surprisingly high $6.1 \%$ of computer applications are still pending nearly seven and a half years 
after they were filed. ${ }^{50}$ The number of finally abandoned applications-the high end of the grant range-also differs significantly by art unit, from a low of $17.1 \%$ in semiconductors to a high of $37.0 \%$ in the transportation industries.

Table 9 shows that the cross-field differences in grant rates are similar after adjusting for grants to children. ${ }^{51}$

Table 9: Share of January 2001 Applications Patented, with and Without Adjustment for Grants to Child Applications, by PTO Art Unit

\begin{tabular}{|l|l|l|}
\hline \multicolumn{1}{|c|}{ Art Unit } & $\begin{array}{c}\text { Share of } \\
\text { Applications } \\
\text { Patented }\end{array}$ & $\begin{array}{c}\text { Share Patented, } \\
\text { After Accounting } \\
\text { for Grants to } \\
\text { Children }\end{array}$ \\
\hline $\begin{array}{l}\text { 1600 Biotechnology and Organic } \\
\text { Chemistry } \\
\text { (Art Units 1600-61) }\end{array}$ & $62 \%$ & $64 \%$ \\
\hline $\begin{array}{l}\text { 1700 Chemical and Materials Engineering } \\
\text { (Art Units 1700-75) }\end{array}$ & $74 \%$ & $77 \%$ \\
\hline $\begin{array}{l}\text { 2100 Computer Architecture, Software \& } \\
\text { Information Security } \\
\text { (Art Units 2100-95) }\end{array}$ & & \\
\hline $\begin{array}{l}\text { 2600 Communications } \\
\text { (Art Units 2600-97) }\end{array}$ & $58 \%$ & $58 \%$ \\
\hline $\begin{array}{l}\text { 2800 Semiconductors, Electrical and } \\
\text { Optical Systems and Components } \\
\text { (Art Units 2800-91) }\end{array}$ & $68 \%$ & $68 \%$ \\
\hline $\begin{array}{l}\text { 3600 Transportation, Construction, } \\
\text { Electronic Commerce, Agriculture, } \\
\text { National Security, and License and } \\
\text { Review } \\
\text { (Art Units 3610-83) }\end{array}$ & $83 \%$ & $84 \%$ \\
\hline $\begin{array}{l}\text { 3700 Mechanical Engineering, } \\
\text { Manufacturing, and Products } \\
\text { (Art Units 3700-67) }\end{array}$ & & \\
\hline
\end{tabular}

50 While many of these applications are on appeal, there were some applications still pending that had received only a nonfinal rejection.

51 Because of the data limitations mentioned earlier, this table shows grant rates through April 2008, but adds only those continuations patented through April 2006. As a result, it understates the grant rate, though likely not significantly. 
Cross-field disparities are also seen in the grant rates of individual patent classes reported in Appendix A. Here, the ranges are much wider, as one might expect. The share of applications resulting in patents (those where the original application or a child application was patented) the lower end of the grant range, vary from a low of only $16.1 \%$ in business methods to a high of $97.0 \%$ in Class 365, covering "static information storage and retrieval., ${ }^{32}$ The high end of the range, abandoned applications, also varies from a low of 5.0\% in Class 365 to a high of $69.7 \%$ in business methods.

While much of the academic and policy discussion about patent policy focuses on differences across industries-primarily IT versus biomedical inventions-Appendix A also shows significant differences within broad technological categories. For example, in the various "data processing" classes the share of patented applications ranges from $16 \%$ to $90 \%$. Similarly, grant rates in Class 604 "surgery" (87.4\%) are quite a bit higher than those for Class 424 “drugs” (57.1\%) and Class 435 “molecular biology” (50.9\%).

Finally, given the recent academic and policy controversies relating to patenting software, we examined this field in particular. Though defining "software" patents is notoriously difficult, we used the Graham-Mowery U.S. patent class-based definition of software patents to create a measure of software patent grant rates across classes. ${ }^{53}$ Table 10 reports the results:

Table 10: Status of Software and Other Patent Applications

\begin{tabular}{|l|l|l|l|}
\hline & Share Abandoned & Share Patented & Share Pending \\
\hline $\begin{array}{l}\text { Nonsoftware } \\
(\mathrm{N}=8,806)\end{array}$ & $26.8 \%$ & $71.5 \%$ & $1.8 \%$ \\
\hline $\begin{array}{l}\text { Software } \\
(\mathrm{N}=1,154)\end{array}$ & $31.7 \%$ & $63.0 \%$ & $5.3 \%$ \\
\hline
\end{tabular}

52 These numbers are accurate as of April 2008 but do not include any adjustments for continuations. As a result, they understate the true grant rate by, on average, $2 \%$.

53 See Stuart J.H. Graham \& David C. Mowery, Intellectual Property Protection in the U.S. Software Industry, in PATENTS IN THE KNOWLedGe-BASED ECONOMY 219 (Wesley M. Cohen \& Stephen A. Merrill eds., 2003). For other definitions, see Bronwyn H. Hall \& Megan MacGarvie, The Private Value of Software Patents 13-19 (Nat'l Bureau of Econ. Res., Working Paper No. 12195, 2006, revised 2007), available at http://elsa.berkeley.edu/ bhhall/papers/HallMacGarvie_April07.pdf; James Bessen \& Robert M. Hunt, An Empirical Look at Software Patents 7-13 (Res. on Innovation \& Boston Univ. Sch. of Law Working Paper No. 03-17/R, 2004), available at http://www.researchoninnovation.org/swpat.pdf. None of these definitions are perfect; the only way to truly identify a software patent may be to read each one with care. See John R. Allison \& Ronald J. Mann, The Disputed Quality of Software Patents, 85 WASH. U. L. REV. 297, 308-10 (2007). Our automated approach to the data does not allow that level of detail. 
Overall, about $12 \%$ of the applications in our sample are software. The odds that a software patent is finally abandoned are somewhat higher than for a nonsoftware patent-31.7\% of software patents, and $26.8 \%$ of nonsoftware patents, were finally abandoned. And more software patents than nonsoftware patents were still pending more than seven years after being filed-5.3\% of software patents versus $1.8 \%$ of nonsoftware patents. This is quite striking given the rapid pace of change in the software industry. The result of these two differences is that grant rates in software are lower than overall grant rates: $63 \%$ versus $72 \%{ }^{54}$

While few should be surprised at the existence of industry-specific differences in patent grants, many people will be surprised-as indeed we are - at which industries have the highest grant rates. The received wisdom is that the problem of bad patents "rubber-stamped" by the PTO is largely confined to the IT industries. In fact, however, what we find is rather more complex. IT is hardly monolithic. Indeed, it includes the art units with both the highest and the lowest grant rates. The industry in which the grant rate is lowest is the computer industry, the very one in which many people would have said bad patents were most common. ${ }^{55}$ Similarly, the PTO rejects the highest share of applications in the field of business methods, from which a disproportionate number of complaints about the patent system arise. ${ }^{56}$

Grant rate data cannot provide a complete picture of the rigor of patent prosecution across fields, since this rigor could feed back to the quality of applications submitted. That is, a tough examination could deter frivolous filings, while a lax examination could encourage them, with the result that the tougher groups end up having fewer bad applications to reject and the laxer groups have more. ${ }^{57}$ It is difficult to test this, because under this scenario application volume, quality, and the rigor of examination would not be independent. But note that the data in Table 8 and Appendix A show little

\footnotetext{
54 The grant rate for software patents versus other patents does not change much after adjusting for whether any child applications result in patents.

55 Allison and Mann find that the software patents that do issue tend to be of higher quality—as far as that can be measured by objective measures like prior art citations - than other types of patents. Allison \& Mann, supra note 53, at 327-29. This is consistent with our results, and inconsistent with the idea that at least modern software patents are disproportionately "bad."

56 As the data in our separate analysis show, these differences persist if we examine the subset of applications where "opting out" of publication was not possible.

57 See ADAM B. JAFFE \& JOSH LERNER, INNOVATION AND ITS DISCONTENTS: HOW OUR BROKEN PATENT System Is ENDANGERING INNOVATION AND PROGRESS, AND WhAT TO Do ABOUT IT 165 (2004) (discussing this possibility).
} 
systematic relationship between grant rates and application volume across art units, suggesting that examination rigor and application volume are not strongly related.

We also examine this at a more disaggregated level in Figure 1, which shows a scatterplot of grant rates versus application volume by three-digit patent class, with each point representing a specific class, and fitted values from a linear regression of grant rates on volume.

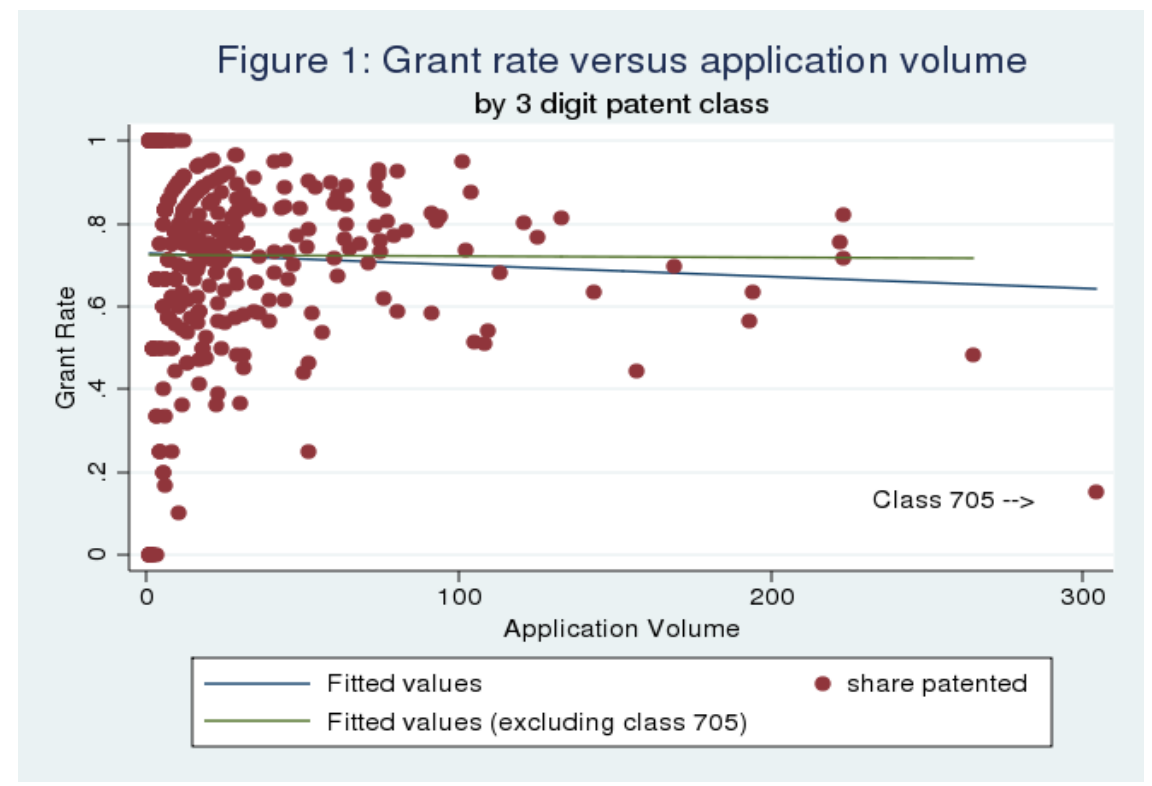

The data show a negative relationship between the grant rate and application volume, potentially suggesting that a feedback effect is at work: applicants in a few classes are flooding the PTO with frivolous claims that the PTO is rejecting. But this negative relationship is driven by one particular classClass 705 for business methods - and is statistically insignificant. And after excluding this class, the slope of the line is essentially zero-there is no evidence of a relationship between application volume and grant rates. While it is impossible to know this for sure, absent some evidence on application quality (as opposed to simply volume) by class, these data undercut the notion that "flooding the patent office" alone explains the patterns of cross-field differences in the grant rates we highlighted above. 
Class 705 is interesting not only because it is the leading class in terms of application volume and has the lowest grant rate among high volume classes, but also because the PTO initiated a specific "quality control" measure in this class in March 2000: the "second pair of eyes" review (SPER), under which applications are subjected to mandatory assessment by more than one examiner before being allowed. $^{58}$ One possible explanation for the low grant rate in this class is that the second pair of eyes is working, and that the grant rate reflects better rigor during examinations, rather than application volume. ${ }^{59}$

Given the timing of the applications, shortly before the "dot com" bust, it is also possible that the abandonments in Class 705 reflect business closings rather than rejections by examiners. To examine this, we analyzed the last transaction before abandonments in this class, and found that $75 \%$ of these were substantive office actions by the PTO, significantly higher than the analogous share for abandoned patents in other classes reported above. That is, the bulk of abandonments in Class 705 do not appear to be due to applicants' exit from the industry, but rather to PTO scrutiny. While this requires more research, it is consistent with the argument that the SPER is working. ${ }^{60}$

\section{IMPLICATIONS}

The PTO is doing a better job than many people think. While it grants patents to more than $70 \%$ of those who apply, the PTO is not a rubber stamp. It rejects a small but nontrivial percentage of applications (15\%-20\%), and still more applications are abandoned for business reasons. While the rejection percentage may seem low, it is worth remembering that the PTO has no power to finally reject a determined applicant. The fact that it nonetheless succeeds in doing so in a nontrivial number of cases is notable. So is the fact that a second pair of eyes seems correlated with a significant increase in actual

58 For discussion of the SPER process, see Allison \& Hunter, supra note 49, at 734-35.

59 Id.

60 Of course, the fact that SPER leads to more rejections in Class 705 doesn't mean it is an unalloyed success. Allison and Hunter demonstrate that its adoption in Class 705 led applicants to try to characterize their business method patents in ways that got them out of Class 705. Id. It is possible that the applications that were not so characterized were systematically weaker than the ones that avoided Class 705 . Nonetheless, Allison and Hunter's objection applies only to a class-specific use of SPER, and wouldn't condemn a broader application of the policy to all art units. 
rejections. ${ }^{61}$ Further, in a significant majority of cases, the prosecution process requires the applicant to amend her claims, presumably to make them narrower. ${ }^{62}$ Requiring an applicant to narrow a patent provides a useful social function akin to weeding out bad patents. We can think of it as weeding out bad or overbroad claims in otherwise good patents.

Finally, our data underscore the dramatic disparities between industries in how they experience the patent prosecution process. They do so, however, in surprising ways. There is no monolithic "IT versus pharma" divide in the treatment of patent applications; rather, semiconductor patents and software patents look very different, with biotechnology and pharmaceuticals falling somewhere in between. But overall, those industries that are most identified with bad patents (computer software, hardware, and business methods) turn out to be those with the lowest grant rates. This could suggest that the conventional wisdom about cross-field differences in examination rigor is incorrect, or that more rigorous patent examination may not improve patent quality. As noted above, we cannot make these claims definitively, absent more information about the underlying quality of applications submitted. But our findings do suggest that debates about patent system reform need to move beyond a narrow focus on the grant rate. The assumption that the PTO is a rubber stamp, turning out software and business method patents regardless of quality, turns out to be a myth.

61 We emphasize that we cannot demonstrate that the SPER in Class 705 is responsible for the much higher rate of rejection in that class. We can confirm that the abandonments in that class were not business decisions. But an alternate explanation is that applications in that class were of abnormally low quality. Allison and Hunter find that the patents that issued from Class 705 were of higher quality than other types of patents. See Allison \& Hunter, supra note 49, at 785 . That doesn't exclude the possibility that the rejected applications were of unusually low quality, though it does seem to make it less likely.

62 See Lemley \& Sampat, supra note 35 (documenting this). 


\section{APPENDIX A: STATUS OF APPLICATIONS BY THREE-Digit PTO ClASS AS OF APRIL 2008, TOP FIFTY CLASSES BY VOLUME}

\begin{tabular}{|c|c|c|c|c|c|c|}
\hline Class & Class Name & $\mathrm{N}$ & $\begin{array}{l}\text { Abandoned } \\
(\%)\end{array}$ & $\begin{array}{l}\text { Pending } \\
\text { (\%) }\end{array}$ & $\begin{array}{l}\text { Patented } \\
(\%)\end{array}$ & $\begin{array}{l}\text { Parent or } \\
\text { Child } \\
\text { Patented }^{63} \\
\text { (\%) }\end{array}$ \\
\hline 705 & $\begin{array}{l}\text { Data Processing: } \\
\text { Financial, business } \\
\text { practice, management, } \\
\text { or cost/price } \\
\text { determination } \\
\end{array}$ & 304 & 69.7 & 15.1 & 15.1 & 16.1 \\
\hline 709 & $\begin{array}{l}\text { Electrical Computers } \\
\text { and Digital Processing } \\
\text { Systems: } \\
\text { Multicomputer data } \\
\text { transferring }\end{array}$ & 265 & 41.5 & 10.2 & 48.3 & 48.3 \\
\hline 257 & $\begin{array}{l}\text { Active Solid-State } \\
\text { Devices }\end{array}$ & 223 & 17 & 0.9 & 82.1 & 84.1 \\
\hline 370 & $\begin{array}{l}\text { Multiplex } \\
\text { Communications } \\
\end{array}$ & 223 & 26 & 2.2 & 71.7 & 71.7 \\
\hline 438 & $\begin{array}{l}\text { Semiconductor Device } \\
\text { Manufacturing: } \\
\text { Process } \\
\end{array}$ & 222 & 23.9 & 0.5 & 75.7 & 76.7 \\
\hline 345 & $\begin{array}{l}\text { Computer Graphics } \\
\text { Processing and } \\
\text { Selective Visual } \\
\text { Display Systems } \\
\end{array}$ & 194 & 34.5 & 2.1 & 63.4 & 63.4 \\
\hline 455 & Telecommunications & 193 & 36.3 & 7.3 & 56.5 & 56.5 \\
\hline 428 & $\begin{array}{l}\text { Stock Material or } \\
\text { Miscellaneous Articles } \\
\end{array}$ & 169 & 30.2 & 0 & 69.8 & 75.8 \\
\hline 707 & $\begin{array}{l}\text { Data Processing: } \\
\text { Database and file } \\
\text { management or data } \\
\text { structures }\end{array}$ & 157 & 47.8 & 7.6 & 44.6 & 45.6 \\
\hline 713 & $\begin{array}{l}\text { Electrical Computers } \\
\text { and Digital Processing } \\
\text { Systems: Processing } \\
\text { architectures ... (e.g., } \\
\text { processors) }\end{array}$ & 143 & 29.4 & 7 & 63.6 & 65.6 \\
\hline
\end{tabular}

63 As we noted above, our data on the status of continuation applications ends in April 2006, while our data on the status of parent applications ends in April 2008. Accordingly, the figures in this column are lower bounds, indicating whether a parent application was patented by April 2008, or a child of that application was patented by April 2006. 


\begin{tabular}{|c|c|c|c|c|c|c|}
\hline Class & Class Name & $\mathrm{N}$ & $\begin{array}{l}\text { Abandoned } \\
(\%)\end{array}$ & $\begin{array}{l}\text { Pending } \\
(\%)\end{array}$ & $\begin{array}{l}\text { Patented } \\
(\%)\end{array}$ & $\begin{array}{l}\text { Parent or } \\
\text { Child } \\
\text { Patented }^{63} \\
(\%)\end{array}$ \\
\hline 359 & $\begin{array}{l}\text { Optics: Systems and } \\
\text { elements }\end{array}$ & 133 & 18 & 0.8 & 81.2 & 85.2 \\
\hline 375 & $\begin{array}{l}\text { Pulse or Digital } \\
\text { Communications }\end{array}$ & 125 & 18.4 & 4.8 & 76.8 & 76.8 \\
\hline 385 & Optical Waveguides & 121 & 19.8 & 0 & 80.2 & 80.2 \\
\hline 348 & Television & 113 & 26.5 & 5.3 & 68.1 & 68.1 \\
\hline 424 & $\begin{array}{l}\text { Drug, Bio-Affecting } \\
\text { and Body Treating } \\
\text { Compositions }\end{array}$ & 109 & 38.5 & 7.3 & 54.1 & 57.1 \\
\hline 435 & $\begin{array}{l}\text { Chemistry: Molecular } \\
\text { Biology and } \\
\text { Microbiology }\end{array}$ & 108 & 45.4 & 3.7 & 50.9 & 50.9 \\
\hline 280 & Land Vehicles & 105 & 48.6 & 0 & 51.4 & 52.4 \\
\hline 382 & Image Analysis & 104 & 12.5 & 0 & 87.5 & 87.5 \\
\hline 358 & $\begin{array}{l}\text { Facsimile and Static } \\
\text { Presentation } \\
\text { Processing }\end{array}$ & 102 & 23.5 & 2.9 & 73.5 & 73.5 \\
\hline 365 & $\begin{array}{l}\text { Static Information } \\
\text { Storage and Retrieval }\end{array}$ & 101 & 5 & 0 & 95 & 97.0 \\
\hline 324 & $\begin{array}{l}\text { Electricity: Measuring } \\
\text { and testing }\end{array}$ & 94 & 18.1 & 0 & 81.9 & 81.9 \\
\hline 439 & Electrical Connectors & 93 & 19.4 & 0 & 80.6 & 81.6 \\
\hline 361 & $\begin{array}{l}\text { Electricity: Electrical } \\
\text { systems and devices }\end{array}$ & 91 & 17.6 & 0 & 82.4 & 84.4 \\
\hline 514 & $\begin{array}{l}\text { Drug, Bio-Affecting } \\
\text { and Body Treating } \\
\text { Compositions }\end{array}$ & 91 & 38.5 & 3.3 & 58.2 & 62.2 \\
\hline 73 & Measuring and Testing & 83 & 21.7 & 0 & 78.3 & 80.3 \\
\hline 347 & $\begin{array}{l}\text { Incremental Printing of } \\
\text { Symbolic Information }\end{array}$ & 80 & 6.2 & 1.2 & 92.5 & 95.5 \\
\hline 379 & $\begin{array}{l}\text { Telephonic } \\
\text { Communications }\end{array}$ & 80 & 40 & 1.2 & 58.8 & 58.8 \\
\hline 714 & $\begin{array}{l}\text { Error } \\
\text { Detection/Correction } \\
\text { and Fault } \\
\text { Detection/Recovery }\end{array}$ & 79 & 22.8 & 0 & 77.2 & 78.2 \\
\hline 250 & Radiant Energy & 77 & 19.5 & 0 & 80.5 & 82.5 \\
\hline
\end{tabular}




\begin{tabular}{|c|c|c|c|c|c|c|}
\hline Class & Class Name & $\mathrm{N}$ & $\begin{array}{l}\text { Abandoned } \\
(\%)\end{array}$ & $\begin{array}{l}\text { Pending } \\
\text { (\%) }\end{array}$ & $\begin{array}{l}\text { Patented } \\
(\%)\end{array}$ & $\begin{array}{l}\text { Parent or } \\
\text { Child } \\
\text { Patented }^{63} \\
(\%) \\
\end{array}$ \\
\hline 430 & $\begin{array}{l}\text { Radiation Imagery } \\
\text { Chemistry: Process, } \\
\text { composition, or } \\
\text { product thereof } \\
\end{array}$ & 76 & 14.5 & 0 & 85.5 & 88.5 \\
\hline 704 & $\begin{array}{l}\text { Data Processing: } \\
\text { Speech signal } \\
\text { processing, linguistics, } \\
\text { language translation, } \\
\text { and audio compression }\end{array}$ & 76 & 36.8 & 1.3 & 61.8 & 61.8 \\
\hline 340 & $\begin{array}{l}\text { Communications: } \\
\text { Electrical } \\
\end{array}$ & 75 & 21.3 & 2.7 & 73.3 & 74.3 \\
\hline 600 & Surgery & 75 & 25.3 & 1.3 & $76.0 \%$ & 80.0 \\
\hline 123 & $\begin{array}{l}\text { Internal-Combustion } \\
\text { Engines }\end{array}$ & 74 & 6.8 & 0 & 91.9 & 91.9 \\
\hline 360 & $\begin{array}{l}\text { Dynamic Magnetic } \\
\text { Information Storage or } \\
\text { Retrieval }\end{array}$ & 74 & 8.1 & 0 & 86.5 & 88.5 \\
\hline 399 & Electrophotography & 74 & 12.2 & 1.4 & 93.2 & 95.2 \\
\hline 369 & $\begin{array}{l}\text { Dynamic Information } \\
\text { Storage or Retrieval }\end{array}$ & 73 & 11 & 0 & 79.5 & 79.5 \\
\hline 701 & $\begin{array}{l}\text { Data Processing: } \\
\text { Vehicles, navigation, } \\
\text { and relative location } \\
\end{array}$ & 73 & 19.2 & 1.4 & 89 & 90.0 \\
\hline 362 & Illumination & 71 & 29.6 & 0 & 70.4 & 70.4 \\
\hline 310 & $\begin{array}{l}\text { Electrical Generator or } \\
\text { Motor Structure }\end{array}$ & 68 & 25 & 0 & 75 & 78.0 \\
\hline 429 & $\begin{array}{l}\text { Chemistry: Electrical } \\
\text { current producing } \\
\text { apparatus, product, } \\
\text { and process }\end{array}$ & 65 & 26.2 & 0 & 73.8 & 75.8 \\
\hline 156 & $\begin{array}{l}\text { Adhesive Bonding and } \\
\text { Miscellaneous } \\
\text { Chemical Manufacture }\end{array}$ & 64 & 10.9 & 0 & 79.7 & 82.7 \\
\hline 327 & $\begin{array}{l}\text { Miscellaneous Active } \\
\text { Electrical Nonlinear } \\
\text { Devices, Circuits, and } \\
\text { Systems }\end{array}$ & 64 & 14.1 & 1.6 & 89.1 & 91.1 \\
\hline 604 & Surgery & 64 & 20.3 & 0 & 84.4 & 87.4 \\
\hline 710 & $\begin{array}{l}\text { Electrical Computers } \\
\text { and Digital Data } \\
\text { Processing Systems: } \\
\text { Input/output }\end{array}$ & 63 & 20.6 & 3.2 & 76.2 & 76.2 \\
\hline
\end{tabular}


[Vol. 58

\begin{tabular}{|c|c|c|c|c|c|c|}
\hline Class & Class Name & $\mathrm{N}$ & $\begin{array}{l}\text { Abandoned } \\
(\%)\end{array}$ & $\begin{array}{l}\text { Pending } \\
(\%)\end{array}$ & $\begin{array}{l}\text { Patented } \\
\text { (\%) }\end{array}$ & $\begin{array}{l}\text { Parent or } \\
\text { Child } \\
\text { Patented }^{63} \\
\text { (\%) }\end{array}$ \\
\hline 349 & $\begin{array}{l}\text { Liquid Crystal Cells, } \\
\text { Elements, and Systems }\end{array}$ & 61 & 11.5 & 1.6 & 86.9 & 86.9 \\
\hline 700 & $\begin{array}{l}\text { Data Processing: } \\
\text { Generic Control } \\
\text { Systems or Specific } \\
\text { Applications }\end{array}$ & 61 & 32.8 & 0 & 67.2 & 67.2 \\
\hline 264 & $\begin{array}{l}\text { Plastic and } \\
\text { Nonmetallic Article } \\
\text { Shaping or Treating: } \\
\text { Processes }\end{array}$ & 60 & 15 & 0 & 71.7 & 72.7 \\
\hline 313 & $\begin{array}{l}\text { Electric Lamp and } \\
\text { Discharge Devices }\end{array}$ & 60 & 28.3 & 0 & 85.0 & 87.0 \\
\hline 711 & $\begin{array}{l}\text { Electrical Computers } \\
\text { and Digital Processing } \\
\text { Systems: Memory }\end{array}$ & 59 & 10.2 & 0 & 89.8 & 89.8 \\
\hline
\end{tabular}

